\title{
Anotações sobre a pauta do telejornalismo brasileiro: um telejornal bom para cachorro
}

NOTES ON THE AGENDA OF THE BRAZILIAN NEWSCAST: A VERY GOOD TV NEWSCAST

\section{Ana Carolina Rocha Pessôa Temer}

Professora do Programa de Pós-Graduação da Faculdade de Informação e Comunicação - FIC da Universidade Federal de Goiás. Doutora e mestre em Comunicação pela Universidade Metodista de São Paulo. Especialista em Sociologia pela Universidade Federal de Uberlândia e Bacharel em jornalismo pela Escola de Comunicação da Universidade Federal do Rio de Janeiro (UFRJ). E-mail: anacarolina.temer@gmail.com

\section{Simone Antoniaci Tuzzo}

Professora do Programa de Pós-Graduação da Faculdade de Informação e Comunicação - FIC da Universidade Federal de Goiás. Doutora em Comunicação pela Universidade Federal do Rio de Janeiro (UFRJ). Mestre e bacharel em Comunicação Social pela Universidade Metodista de São Paulo.

E-mail: simonetuzzo@hotmail.com

Recebido em 18 de março de 2015. Aprovado em 28 de setembro de 2015.

\section{Resumo}

Este trabalho é parte de uma reflexão continuada sobre Comunicação e Jornalismo desenvolvida pelo Laboratório de Leitura Crítica da Mídia da Faculdade de Comunicação e Informação da Universidade Federal de Goiás (UFG). O foco da análise são as reportagens realizadas sobre animais domésticos no ano de 2014, período marcado por outras notícias de grande impacto. $\mathrm{O}$ trabalho parte de considerações sobre aspectos específicos do jornalismo e da questão dos valores-notícia como base para análise da construção da pauta e do espelho dos telejornais exibidos nacionalmente pela Rede Globo, buscando apontar a inclusão da uma nova pauta: os animais de estimação e sua presença na sociedade contemporânea.

Palavras-chave: Telejornalismo. Valores-notícia. Mudanças Sociais. Organização da Realidade. 


\section{Abstract}

This work is part of a continuing reflection on Communication and Journalism, developed by the Laboratory for Critical Reading of Media, in the Faculdade de Comunicação e Informação of Universidade Federal de Goiás (UFG). The focus of the analysis are the reports made on domestic animals in the year of 2014, a period marked by other news of great impact. This paper stems from considerations on specific aspects of journalism and the issue of news values as a basis for analysis of the task assignment and the construction of news script of television newscasts aired nationally by Rede Globo, trying to point out the inclusion of a new task assignment: pets and their presence in contemporary society.

Keywords: Telejournalism. News values. Social changes. Organization of reality.

\section{Introdução: crise no telejornalismo ou crise na cobertura jornalística}

A segunda década do século XXI será anotada no telejornalismo brasileiro como um período de mudanças e questionamentos. $\mathrm{O}$ acesso às novas tecnologias, a multiplicação das emissoras de sinal codificado (a cabo ou via satélite), mas principalmente a crescente importância das redes sociais, fez que as emissoras de televisão brasileiras vissem despencar seus números no Ibope, gerando uma busca caótica de tentativas de recuperação e uma consequente mudança nas pautas dos telejornais. Salvo alguns resultados pontuais, a queda da audiência atingiu o conjunto da programação televisiva, mas como era previsível, foi particularmente sentida pela Rede Globo, que detinha (detêm) números majoritários da audiência. Especialmente no telejornalismo da Rede, que ao longo da história tem conjugado altos investimentos técnicos com uma cobertura ampla (ainda que não equânime) de todo território nacional, os efeitos dos números têm sido mal recebidos e as tentativas de reverter essa tendência são consideradas um desafio.

Embora ainda não se possa fazer uma análise ampla dos números de 2014, esse foi um ano ruim na história do Jornal Nacional no Ibope. O telejornal teve um recorde negativo no dia 11 de abril de 2014, quando atingiu 18,3 pontos na audiência (cada ponto equivale a 65 mil domicílios em São Paulo), abaixo da sua menor média negativa de 19 pontos em 31 de dezembro de 2013 (FOLHA, 2014).

Apontado historicamente como o principal telejornal do país, acusado de eleger presidentes e impor pautas para a nação, a crise mostra-se mais grave quando se percebe que a perda é progressiva. O mais antigo noticioso da Rede Globo ainda no ar, exibido pela 
primeira vez em $1^{\circ}$ de setembro de 1969 com o objetivo confesso de unir o país de norte a sul - "Um telejornal para que 56 milhões de brasileiros tenham mais coisa em comum" (VEJA, 1952 apud REZENDE, 1997, p. 116) -, o telejornal pode ser considerado o marco de um Brasil que começava a viver a "era da comunicação espacial" (REZENDE, 1997, p. 116) fechou o seu terceiro ano consecutivo com média inferior a 30 pontos, concretizando a perda de um terço de audiência nos últimos dez anos. Uma despencada considerável para o veículo que já deteve o virtual monopólio da audiência nacional.

A história da Rede Globo, seus vínculos diretos e indiretos com o governo militar, a questão da qualidade técnica do seu telejornalismo e as mudanças enfrentadas na pauta e no conteúdo em função das mudanças decorrentes do processo de democratização do país evidentemente colaboraram para as mudanças nas relações da emissora com a audiência. No entanto, nessa relação não devem ser esquecidas outras questões relevantes, entre as quais a presença da internet, das redes sociais, e das múltiplas possibilidades de acesso à informações jornalísticas (e não jornalísticas), além de novas formas de interatividade midiatizada. Nesse cenário, cabe repensar o modelo tradicional de telejornal como espaço privilegiado de acesso à informação.

Ainda que a complexidade dessa questão não possa ser exaurida em um único artigo científico, a proposta deste trabalho é, entre um pouco de bom humor e rigor científico, fazer um diagnóstico da pauta do telejornalismo da Rede Globo, buscando não só entender como é construído o conteúdo desse telejornalismo, mas também contrapondo dois elementos: as matérias factuais ou duras, que têm elementos característicos das notícias (fatos novos, de interesse público e de interesse do público) a matérias consideradas mais leves: matérias de serviço e matérias de interesse humano, em particular as matérias que dizem respeito ao "mundo animal", aos pets e às novas organizações sociais e familiares que incluem a presença dos bichos de estimação.

Com esse objetivo, considera-se que algumas informações e/ou coberturas divulgadas pelo jornalismo são definidoras do caráter da atividade, interferindo - e definindo - a percepção do público e dos profissionais de imprensa sobre os elementos que definem o ethos do jornalismo.

\section{Sobre a televisão no Brasil}

A “comunicação é uma sucessão de efeitos multiplicadores" (LUHMANN, 2011). Uma informação, uma vez divulgada, sai do controle de quem a divulgou. Mesmo em um contato primário de comunicação interpessoal é interpretada e reinterpretada conforme circula na comunidade e nasociedade. Esse efeito multiplicador ganha um novo contorno 
na comunicação midiada ${ }^{1}$ e se diferencia de outros processos comunicacionais porque exige a mediação de veículos técnicos e/ou eletroeletrônicos que ampliam a possibilidade de recepção das mensagens. Grupos de especialistas, em geral com formação profissional, se servem desses aparatos técnicos para a difusão de conteúdos simbólicos para um público numericamente expressivo, geograficamente disperso e com um significativo grau de heterogeneidade. Nesse contexto, a televisão é a grande mídia ${ }^{2}$ e se caracteriza por utilizar a plasticidade da imagem e o potencial sedutor de conteúdos emocionais para ampliar seu processo comunicacional.

Essa relação adquire contornos especiais na televisão brasileira de sinal aberto, que nasceu dentro da iniciativa privada como empresa voltada para o lucro e, portanto, dependente da audiência e do apoio comercial dos anunciantes. Em termos gerais, a Rede Globo ${ }^{3}$ se consolidou a partir da capitalização de uma grande fatia da audiência, ou ainda por meio de um virtual monopólio da audiência, trazendo para si um público com pouca possibilidade de acesso à cultura acadêmica e consolidando sua importância como veículo informativo e jornalístico em um contexto no qual a miséria e a modernização tecnoburocrática convivem e se retroalimentam.

Embora essa relação envolva também uma convivência/dependência com o governo militar, a televisão brasileira se estabelece principalmente de forma interligada com um modelo capitalista industrial e urbano, no qual o ponto principal é a abertura e a consolidação de mercados consumidores. Em outros termos, um modelo voltado para a valorização do consumo, que busca abrir espaço para venda de produtos e serviços. Embora na atualidade conviva e concorra com outras redes de televisão - também grandes mídias - que crescem em termos de poder e audiência, o modelo de concentração da posse das

1 Para evitar confusões recorrentes no campo da Comunicação no Brasil, adota-se neste texto a percepção de que os termos media e mediatização dizem respeito aos meios de comunicação, uma vez que media é o plural de médium, palavra de origem latina que significa, em uma tradução direta, meio. Já os termos mídia e midiatização, respectivamente têm, strictu sensu, o mesmo significado, já que se originam a partir da pronúncia em inglês da mesma palavra. No entanto, o seu uso aportuguesado pelos brasileiros por meio do neologismo mídiaaplica-se apenas aos meios de comunicação que ampliam e/ou reproduzem as mensagens, e portanto, aceleram e alteram a sua circulação.

2 Neste artigo, a expressão grande mídia diz respeito aos veículos e produtos/programas que são veiculados por empresas pertencentes aos grandes grupos de comunicação. Trata-se, portanto, de empresas que têm a hegemonia no processo midiático. As Organizações Globo são um exemplo de grande mídia, mas se encaixam nessa expressão também o SBT, as empresas do grupo Record, a Rede TV!, o grupo Bandeirantes, os jornais Folha de S. Paulo e O Estado de S. Paulo, as empresas do Grupo Abril e o Grupo RBS, entre outras.

3 Empresas Globo de Comunicação, um conglomerado que soma mais de 100 empresas e um número superior a 20 mil funcionários começa bem antes da Rede Globo. O jornal O Globo, solidamente instalado no Rio de Janeiro, existe desde 1925 e em 1944 é inaugurada a Rádio Globo. A televisão chega ao Rio de Janeiro em 20 de janeiro de 1951, mas apenas em 30 de dezembro de 1957 o Presidente Juscelino Kubitschek de Oliveira outorga a concessão da TV Globo Rio de Janeiro. A nova emissora - Canal 4 - entra no ar em abril de 1965, um ano depois do golpe militar de 1964 "que atrelou definitivamente a economia do país ao capitalismo internacional" (KEHL, 1986, p. 173). 
emissoras de televisão de sinal aberto continua forte, uma vez que grande parte das concessões de emissoras está nas mãos de algumas poucas famílias.

Sobre esse ponto, é necessário refletir que a concentração da posse das mídias nos leva simultaneamente a um processo de midiatização e a um prejuízo da pluralidade das mensagens e eventuais debates sobre essas mensagens nos demais espaços sociais. Galeano (2006, p. 149-150) lembra que "a ditadura da palavra única e da imagem única, bem mais devastadora que a do partido único, impõe em todo lugar um mesmo modo de vida". A concentração da propriedade das mídias compromete o exercício da cidadania, pois afeta a exposição dos grupos sociais, reduz a multiplicidade de fontes, determina o enquadramento ${ }^{4}$ e limita o acesso à informação, dificultando a formação de indivíduos bem informados e que possam atuar como cidadãos plenos.

Inserida nessa relação, a televisão (e particularmente a televisão brasileira) se desenvolve a partir de uma relação dialógica desigual, na qual o produtor de conteúdos se insere como uma das poucas opções de lazer e informação do receptor, o que por sua vez contribui para o aumento das contradições e diversidades existentes no interior da sociedade nacional. Dentro dessa perspectiva, portanto, a questão da responsalidade social das mídias na consolidação de hábitos e comportamentos é um tema que já não pode ser evitado.

De fato, emissoras de televisão brasileira tendem a obliterar a função social que thes é atribuída pela legislação brasileira e trabalham principalmente para obter a única coisa que realmente lhes importa: a audiência, uma vez que ela representa o elemento simbólico que lhes abre caminho para ganhos econômicos e para a representatividade social e política, aumentando sua importância como ator social. Em nome dessa lucratividade - real ou potencial - a emissora vem se adaptando ao longo dos anos, inclusive com mudanças significativas no conteúdo do telejornalismo, que tem se traduzido nas pautas - ainda que não necessariamente em novos posicionamentos políticos e percepções econômicas e culturais.

A partir desse panorama e sempre considerando a conjuntura nacional, a Rede Globo e o telejornalismo que ela veicula são espaços paradigmáticos, uma vez que representam por um longo período uma expressão monopolizada da televisão brasileira e permanecem lutando para manter a condição de líder de audiência e emissora definidora dos padrões de produção.

\section{O que é jornalismo?}

Segundo Marcondes Filho (2000, p. 9), a vitória das democracias republicanas e a consequente realização de um modelo burguês e urbano formatou o jornalismo a partir

4 Entende-se enquadramento como a qualidade do texto que determina de que forma as interações se interligam em quadros de construção de sentidos, que modelam as interpretações e ações dos atores envolvidos. 
da lógica da urbe moderna, do espírito empresarial e da ética capitalista ${ }^{5}$, cujo loccus privilegiado é o espaço urbano. Dessa forma trata-se de uma atividade que se cristaliza principalmente a partir de empresas privadas, voltadas para o lucro, mas também de um modelo marcado pela valorização utópica de ideias de liberdade de opinião e expressão.

Enquanto atividade prática, no entanto, o jornalismo é uma forma de mediação do ser humano e sua relação com o mundo e se difere das demais narrativas ou conteúdos simbólicos por privilegiar questões relativas ao cotidiano. O jornalismo é um registro do dia a dia, um conjunto de conteúdos constitutivos da vida diária de um povo, de uma época, de um local. A confiança nessas informações é também reforçada pela relação incondicional do jornalismo com a verdade, com informações reais e verdadeiras. De fato, a relação "a verdade e a atualidade" são os esteios centrais pelos quais a atividade se autolegitima.

O conteúdo jornalístico é uma "representação" do seu tempo, e não pode separá-lo das relações sociais, hábitos, costumes e ações humanas características desse tempo. Mas trata-se também de uma relação complexa, uma vez que o processo histórico de institucionalização do jornalismo envolve a sua aceitação como sistema perito ${ }^{6}$, a soberania das regras jornalísticas como elementos que definem a noticiabilidade e o status dos conteúdos e a importância das mídias como referências informativas para sabermos tudo que é importante para a sociedade (informações, modismos, comportamentos etc.). Consequentemente, o jornalismo está atento às mudanças sociais e culturais e não poderá sobreviver - ou continuar obtendo a atenção dos seus receptores - sem acompanhá-las.

Dessa forma, o jornalismo da grande mídia influencia comportamentos na medida em que o receptor mantém com ele uma relação de confiança e credibilidade, aceitando-o como mediador de tudo que é digno de saber do mundo (GROTH, 2011, p. 177). O jornalismo interfere na vida social, mas o receptor/audiência é a própria razão de existência do jornalismo e, portanto, sua importância não deve ser ignorada. Individualmente cada veículo luta para ampliar sua audiência, uma vez que é ela que define sua importância, seustatus social. Dessa forma o jornalismo funciona a partir de um diálogo social, um espaço para mediação que tanto é influênciado pelas ações, costumes e modismos sociais como também os influencia e eventualmente os consolida.

5 O termo surge a partir da sua utilização por Max Weber no livro A ética protestante e o "espirito" do capitalismo (no original alemão Die protestantische Ethik und der "Geist'des Kapitalismus) que aponta que existe uma ética ou espírito do capitalismo, formada por ideias e hábitos que justificam a procura racional de formas para concretizar o ganho econômico (WEBER, 2003).

6 Entendendo sistema perito como: "sistema de excelência técnica ou competência profissional que organizam grandes áreas dos ambientes material ou social que vivemos hoje" (GIDDENS, 1991, p. 35). 


\section{Sobre o telejornalismo}

Sendo a adaptação para a linguagem televisiva um dos elementos característicos do jornalismo, em princípio o telejornalismo trabalha com os mesmos critérios de qualidade ou elementos valorativos da legitimidade do jornalismo impresso.

Mas o telejornalismo é também uma síntese do jornalismo com a televisão, o que inclui características como a recepção doméstica e a necessidade de estetizar a informação. A narrativa telejornalística é trabalhada de forma que telespectador não necessite se esforçar para compreendê-la, trabalhando a informação a partir de seu apelo emocional.

No caso específico do telejornalismo da Rede Globo, o modelo inclui o uso estratégico de informações rápidas e da tecnologia, colocada como elemento que valoriza - dignifica a informação - e também garante sua qualidade. A opção editoral da Rede Globo, em particular, inclui a valorização de matérias curtas, que permitam a inclusão de vários assuntos (várias matérias jornalísticas) a cada edição telejornalistica.

\section{Uma proposta de pesquisa}

A análise foi centrada especialmente em uma leitura crítica do material efetivamente vinculado e divulgado no último trimestre do ano 2014, nos telejornais da Rede Globo, mas considerando também seus vínculos com outras mídias, em particular a emissora de sinal codificado Globo News e os portais da Rede Globo, buscando apontar as contradições que cercam a cobertura jornalística nesse período. Nesse sentido, a proposta de análise considerou dois pontos, a saber:

a) A tipologia do material jornalístico, conforme definido por Temer (2002), em que o foco está na separação entre os conteúdos/tipos de material jornalístico, separando notícias, repercussões, denúncias, matérias de serviço e matérias de interesse humano.

b) A questão dos jogos de linguagem, um conceito abordado por Wittgenstein (1988, p. 91), que guarda relação com a moderna teoria da argumentação e cujo objeto é "o estudo das técnicas discursivas" (PERELMAN; OLBRECHTSTYTECA, 1989, p. 34) no que se refere aos diferentes usos das palavras e como elas são utilizadas na forma de instrumentos de persuasão, estabelecendo categorias e valores, na elaboração e nas descrições.

7 No original: "el estudio de las técnicas discursivas que permiten provocar o aumentar la adhesión de las personas a las tesis presentadas para su asentimiento". Tradução minha. 
O objetivo do trabalho, portanto, é entender quais valores estão implícitos nas matérias sobre cães e animais domésticos e como elas refletem as mudanças comportamentais e os valores - morais e sociais - da contemporaneidade brasileira.

Sobre essa questão destaca-se ainda que a participacão em jogos de linguagem exige coerência, uma vez que se espera uma verdade no relato que está sendo transmitido (REY MORATÓ, 2007) e a verdade do relato jornalístico/telejornalístico não está só na sua relação com a verdade/fatos verdadeiros, mas também na sua eficácia persuasiva.

Entende-se ainda que os receptores acessam os conteúdos jornalísticos por vários motivos, mas de uma forma geral, ler o jornal, ou mais especificamente, ver o telejornal, está associado a saber das "novidades", do que é novo, atual, tem grande impacto e interesse público e é preferencialmente inédito ou desconhecido dos receptores.

No entanto, as condições e o acesso a essas informações e as condições determinantes do jornalismo ${ }^{8}$ forçam a inclusão de outros tipos de matérias, como as matérias de serviço e material de interesse humano, os chamados fait-divers.

Como o próprio nome já indica, as matérias de interesse humano dizem respeito a tudo que tem interesse para a vida humana e em particular ao que chama atenção pelo aspecto emocional ou curioso, um material que satisfaz a curiosidade do público, em geral sem exigir reflexões. O fait-divers se compatibiliza especialmente com a linguagem televisiva, uma vez que é sensacional por si mesmo: não pede nada, a não ser a atenção do receptor; é uma maneira fácil de garantir a participação efetiva do público com fragilidade na formação acadêmica e/ou acesso à informação crítica.

O estudo envolve também a análise de se e como o telejornal:

a) pratica uma lógica binária, que cultiva os extremos e elimina os matizes na descrição das relações entre os animais domésticos e seus donos e a sociedade;

b) se o texto se caracteriza pela simplificação e eventual uso de linguagem publicitária, inclusive incentivando o uso de produtos e serviços;

c) se baseia na substituição da complexidade pelo uso de estereótipos;

d) se baseia em uma retórica que oculta ou camufla conflitos e problemas;

8 Groth, discípulo de Weber, ao iniciar os estudos sobre as bases da "jornalística", entende que o jornalismo se define a partir de quatro pilares: a atualidade, a difusão pública, a universalidade e a periodicidade. Entretanto, no decorrer do seu desenvolvimento, o jornalismo incorporou também o status de um serviço ao público, uma vez que informa sobre os elementos essenciais à vida diária, dá visibilidade ao Estado e às ações e decisões que afetam a sociedade, ainda que não seja necessariamente um serviço público, no sentido restrito de serviço essencial subsidiado pelo Estado. 
e) se ridiculariza ou ironiza a relação dos humanos com os animais de estimação;

f) se utiliza estratégicas/retóricas voltadas para o humor; g) se é contraditória em seus argumentos.

As unidades de análise envolvem a investigação dos termos e palavras utilizadas em conjunto, de forma que o protocolo da análise está em busca das matrizes argumentativas centrais/principais, que são os elementos geradores das práticas dos jogos de linguagem.

\section{A presença canina na mídia}

Achados arqueológicos datam o início da amizade entre os seres humanos e os cães a partir do desenvolvimento da agricultura. Os cães de caça e de guarda ajudavam as tribos em troca de alimento e abrigo desde antes da existência da escrita e estão presentes, com muitas variações, em muitos continentes. Mas apesar de fazer parte da vida humana desde a pré-história, a transformação do cão como animal de trabalho para animal de estimação é bem mais recente, tendo se popularizado apenas no século XX.

Mais recente também é a entrada dos cães no mundo do espetáculo. As mídias, sempre atentas às sensibilidades dos públicos, não demoraram a explorar a amizade humana com os cães, fazendo-os companheiros de personagens famosos, elevando-os a condição de astros - como no caso de Rin-Tin-Tin ${ }^{9}$ e Lessie ${ }^{10}$.

$\mathrm{Na}$ televisão, a presença dos cães também não demorou a ser usada com chamariz. Além de se referir indiretamente ao tema dando nome a uma telenovela (Vira Lata, exibida no horário das 19 horas, entre abril a setembro de 1996), a Rede Globo inseriu personagens caninos em seus diversos produtos ficcionais. Entre os mais populares estão Titânia (da novela Cama de gato, de 2009), Inês (da novela Por amor, de 1997-1998) e Pepe (da novela Escrito nas estrelas, de 2010).

Também existem atualmente vários programas dedicados ao tema da convivência humano- animal, entre eles $O$ encantador de cães, Meu cão ideal (ambos com Cesar Millan), e, na versão nacional, Missão pet, apresentado por Alexandre Rossi,cuja "assistente" Estopinha, com 2 milhões de amigos no Facebook, comemorou o aniversário de 6 anos com festa beneficente em São Paulo; além de muitos outros programas distribuídos pelos canais segmentados. Aliás, os animais possuem até mesmo um canal, o Animal Planet, que, é claro, tem presença garantida de numerosos caninos.

9 Cão de shows criado pelo produtor cinematográfico Charles Jones, cuja estreia no cinema ocorreu em 1922.

10 O personagem de Lassie foi criado pelo autor anglo-britânico Eric Knight, na novela Lassie Come Home, publicada em 1940 e adaptada ao cinema em 1943. 
No entanto, o telejornalismo, por sua condição diferenciada de serviço público, sempre foi um espaço mais restritivo. Embora seja presumível que algumas notícias tenham envolvido o mundo animal, a colocação dos animais de estimação como ponto central de matérias de serviço ou de interesse humano é um fenômeno relativamente recente, mas que já impressiona pelo volume.

Analisados sob esse ponto, e considerando que o objeto desta pesquisa é o telejornalismo da Rede Globo, temos, no período estudado, um total de 20 matérias jornalisticas nas quais um animal doméstico (predominantemente cachorros) ou questões ligadas a sua vida e seu conforto são elementos centrais. Não foram consideradas matérias nas quais os animais aparecem de forma secundária, compondo um cenário de fundo ou são citados aleatóriamente.

Tabela 1. Distribuição das matérias que possuem animais domésticos nos telejornais veiculados nacionalmente pela Rede Globo em 2014

\begin{tabular}{|c|c|c|c|}
\hline \multicolumn{2}{|r|}{ Data } & Tempo & Retranca \\
\hline \multirow{7}{*}{$\begin{array}{l}\text { Bom } \\
\text { Dia, } \\
\text { Brasil }\end{array}$} & $17 / 07 / 14$ & 2’54” & $\begin{array}{l}\text { Pesquisador de São Paulo desenvolve tecido a partir dos pelos de cachorro } \\
\text { descartados na lavagem }\end{array}$ \\
\hline & $26 / 08 / 14$ & 1'56”' & Cães farejadores são treinados para espantar aves em aeroportos \\
\hline & $08 / 09 / 14$ & 1'59”' & Cadela de estimação salva menina de bandido \\
\hline & $24 / 11 / 14$ & $1 ' 30 ”$ & Polícia investiga matança de cães \\
\hline & $22 / 12 / 14$ & $1 ’ 32 ”$ & $\begin{array}{l}\text { Fidelidade de cão de rua faz parar ambulância dos bombeiros em Brasília (cão } \\
\text { seguiu a ambulância) }\end{array}$ \\
\hline & $23 / 12 / 14$ & 3’33”' & Bandido rouba cão de raça para revender em Brasília \\
\hline & $31 / 12 / 14$ & 2’14" & Cão abandonado vira caso no Rio de Janeiro (vídeo postado nas redes sociais) \\
\hline \multirow{6}{*}{$\begin{array}{l}\text { Jornal } \\
\text { Hoje }\end{array}$} & $26 / 02 / 14$ & 2’44” & Cliente processa pet shop por venda de falso cachorro de raça \\
\hline & $26 / 02 / 14$ & $33 ”$ & Cachorro encontra latas com moedas antigas no quintal dos seus donos \\
\hline & $15 / 05 / 14$ & $42 ”$ & Gata salva menina de ataque de cão feroz \\
\hline & $22 / 07 / 14$ & 1'57'” & Feira mostra novidade do mercado pet \\
\hline & $05 / 09 / 14$ & $1 ’ 52 ”$ & Cachorro ajuda na recuperação de doentes no hospital \\
\hline & $28 / 10 / 14$ & $1,58^{\prime \prime}$ & Feira com produtos para o mercado pet \\
\hline \multirow{7}{*}{$\begin{array}{c}\text { Jornal } \\
\text { Nacional }\end{array}$} & $10 / 04 / 14$ & $1 ’ 22 ”$ & Filhote clonado custa 220 mil \\
\hline & $09 / 08 / 15$ & 2’44” & Animal de estimação é causa de briga entre vizinos \\
\hline & $08 / 09 / 14$ & $33 ”$ & Cadela impede criança de ser violentada \\
\hline & $29 / 10 / 14$ & 2’18” & Salão do automóvel: novos acessórios e cinto de segurança para cães \\
\hline & $03 / 12 / 14$ & 2’03” & Polícia encontra suspeito de envenenar cães e gatos \\
\hline & $10 / 12 / 14$ & $1 ' 50 ”$ & Cachorrinha encontra criança de três anos que fugiu de casa \\
\hline & $22 / 12 / 14$ & 3’29”' & Maneira correta de transportar animais nos carros \\
\hline
\end{tabular}

Obs: não foram localizadas matérias sobre o tema no Jornal da Globo

Fonte: Elaboração das autoras 
Sobre o conjunto do material, nota-se que as matérias estão distribuídas de forma desigual nos quatro telejornais da emissora, sendo em maior número nos telejornais que tem maior duração. Nota-se também que as matérias seguem o padrão da emissora: uma média pouco superior a um minuto e meio, chegando a um máximo de três minutos, e notas cobertas de pouco mais de meio minuto para as matérias de agências de notícia. A regra vale também para as matérias que usam cenas postadas na internet, particularmente nas redes sociais, que usualmente são inseridas em conteúdos elaborados pela emissora.

O maior volume de matérias foi classificado como material de interesse humano (onze matérias) e se destaca por ter uma abordagem leve e marcadamente emocional. São situações nas quais o maior destaque é o valor do animal, em uma reafirmação de sua utilidade ou qualidades.

De forma marcante também, a narrativa é centrada em esteriótipos e na lógica binária (cachorro bom/cachorro útil). A relação do ser humano com o animal é valorizada, com poucas estratégias voltadas para o humor. Não há espaço para o sarcasmo, mas o conteúdo emocional é significativo.

Um total de seis matérias foi classificado como serviço e se caracterizam pelo vínculo com o consumo, o que recai em usos eventuais de linguagem publicitária e o incentivo direto ou indireto a aquisição de produtos ou serviços. A matéria classificada como denúncia - sobre a venda de animais “comuns" como filhotes de raça - igualmente se aproxima da questão do consumo, e é digno de nota o uso da linguagem emocional, inclusive com o depoimento de um comprador que se declara afeiçoado ao animal e que não irá desprezá-lo por não ser de raça pura.

Uma matéria, sobre a matança de animais, foi classificada como notícia ${ }^{11}$, e foi a única que teve uma repercussão poucos dias depois de sua exibição. Em ambos os casos predomina uma retórica que oculta/camulfla a complexidade da situação: o problema é exposto como algo pontual e prontamente resolvido, ignorando a existência de cães abandonados e as consequências sanitárias do problema.

Não há contradições nas matérias, que se caracterizam pela reafirmação de valores como amizade e fidelidade. Em termos gerais, elas se aproximam da definição de Bourdieu para fatos-ônibus: "são fatos que, como se diz, não devem chocar ninguém, que não envolvem disputa, que não dividem, que formam consenso, que interessam a todo mundo, mas de um modo tal que não tocam em nada de importante" (1997, p.73).

11 Considera-se notícia fato novo, de grande impacto, de interesse público e de interesse do público. 


\section{Cachorros na TV, cachorros na sociedade, cachorros na vida social!}

A linguagem utilizada aponta também que os cachorros ganharam status de membro da família e fazem parte das preocupações diárias e do orçamento doméstico. Consequentemente, a humanização dos cachorros determinou a abertura de uma nova frente de consumo de bens para animais de estimação ou foi a descoberta de uma possibilidade de mercado consumidor para animais que fez as campanhas publicitárias e o marketing social criarem nos indivíduos uma necessidade de humanizar os animais? ${ }^{12}$

Finalizando a análise, é digno de nota que, em se tratando de mídia e de Rede Globo, essa relação é reforçada pelo incentivo a esse tipo de comportamento em outros programas de expressão e impacto de audiência, como o Mais Você em que a apresentadora Ana Maria Braga transformou o seu cenário em uma casa e nela habita uma cadela, livre para circular por todos os espaços, tratada como membro da família - inclusive com status de trabalhadora que ajuda a produzir o programa todas as manhãs. Também é emblemático que o programa Encontro com Fátima Bernardes ${ }^{13}$ tivesse dedicado uma edição exclusivamente para o relacionamento dos donos com seus cães ${ }^{14}$.

\section{Conclusão: o cachorro é melhor que gente!}

A análise do material apresentado nos telejornais da Rede Globo aponta algumas excentricidades. Curiosamente, os telejornais que têm um maior número de matérias sobre os animais domésticos são o Bom Dia, Brasil e o Jornal Nacional, considerados os mais voltados para questões políticas e econômicas. Essa relação pode ser explicada de duas formas: primeiro, tratam-se dos telejornais com maior tempo (espaço) da emissora, o que forma um argumento lógico para a maior presença desse material. O segundo aspecto diz respeito ao impacto econômico dessa mudança de hábitos. É significativo que a única matéria jornalística sobre o tema que foi reprisado (novamente exibida em outro

12 O mercado consumidor criado a partir da transformação da relação entre os cachorros e seus donos é promissor, uma vez que um cão pode custar à família uma média de R $\$ 780,00$ por mês, a partir de custos calculados com base em visitas ao veterinário, remédios, vacinas, banho e tosa, tosa higiênica, taxa para buscar e entregar para banho e tosa, diária de hotel, ração, brinquedos, ossinhos, petiscos e biscoitos especiais, além de serviços de passeador e adestrador.

13 O programa leva o nome da apresentadora, mas no dia citado - 9 de janeiro de 2015 - ela estava de férias, sendo substituída por Ana Furtado Lair Renó e Marcos Veras.

14 Nesse programa o assunto principal foi o cão abandonado pelos donos, que também foi matéria no telejornalismo, e cuja matéria será analisada no tópico seguinte.

$90 \frac{\text { Comunicação \& Inovação, PPGCOM/USCS }}{\text { v. 17, n. } 33 \text { (79-94) jan-abr } 2016}$ 
telejornal) fosse justamente sobre as possibilidades (feira de negócios) que essa mudança de comportamento traz para as relações econômicas.

Observado esse aspecto, fica claro que o animal de estimação, e principalmente o cachorro (apenas uma matéria era sobre gatos, e nenhuma sobre outro animal doméstico) ${ }^{15}$, é um personagem, e como todo personagem, tem personalidade. Dentro dessa personalidade, aliás, alguns elementos são visíveis: o cachorro que está nos telejornais da Rede Globo:

a) é caro e consumista. Ele exige mais do que atenção, exige investimentos em equipamentos e cuidados. Não importa a raça, o animal é vaidoso (sic), estando quase sempre adornado com lacinhos, gravatas, detalhes de strass e o que mais for possível. Nesse caso, não se trata apenas do apelo estético, mas também um reforço às possibilidades de negócios que a nova convivência humano-animal proporciona.

b) tem direitos. Para começar, o direito à vida. Uma das reportagens, que aborda a matança dos animais de rua, é bastante clara sobre esse ponto. Mas ele está implícito no conteúdo sobre o tema de uma forma geral. Mas tem também outros direitos: ao carinho e a atenção dos donos, que são eternamente responsáveis por aquilo que cativam $^{16}$. Os momentos de maior indignação das matérias estão nos maus tratos e no abandono. Essa relação fica clara até mesmo na matéria na qual os "compradores" processam um petshop que vendeu um cachorro mestiço como sendo de raça - está presente a defesa do animal que, apesar disso, merece o carinho dos donos - mas o seu maior destaque está na matéria na qual o cachorro é abandonado e amarrado em uma grade pelos seus proprietários. Esse material, assim como vários outros, foi pautado a partir de um vídeo exposto nas redes sociais e mostra não apenas essa relação, mas também como a pauta do telejornal tem sido mais diretamente influenciada pelos receptores (ou, pelo menos, receptores em potencial). De fato, a própria apresentação da matéria jornalística foi pontuada de destaques sobre o número de pessoas que acessaram o vídeo e por comentários sobre a indignação dos internautas e telespectadores sobre o fato. A situação gerou novos comentários, como a posterior adoção do animal por outro casal, que apesar de estar próximo a ter um filho, se apaixonou pelo animal. Indiretamente, essa relação, que foi novamente explorada no dia 9 de janeiro de 2015, no programa

15 Como pode ser observado na Tabela 1, foram propositalmente não consideradas matérias sobre tráfico de animais silvestres e outras sobre animais que não estão no espaço da convivência doméstica.

16 A frase remete a um trecho do livro O Pequeno Princípe, de Antoine de Saint-Exupéry, publicado em 1943. 
Encontro com Fátima Bernardes - um híbrido de informações e entretenimento subjetivamente iguala a importância do cão a da criança ainda por nascer.

c) é surpreendentemente útil: ajuda a recuperação de doentes em hospitais, caça aves perigosas próximas a aeroportos, ajuda na socialização das crianças, protege contra agressões e até acha moedas de ouro escondidas no quintal e também pode ter o pelo descartado transformado em tecido. Nunca é um peso, uma despesa, e mesmo quando indiretamente causa aborrecimentos - como desavenças entre os vizinhos em condomínios - isso ocorre por culpa dos seus proprietários, que não sabem educar/cuidar do animal. Esse detalhe, muitas vezes colocado de forma secundária, é ideologicamente importante, pois justifica os gastos (investimentos?) que são feitos para manter a posse do animal.

d) é fiel e carinhoso, aliás, mais dotado de qualidades humanas desejáveis do que a maior parte dos indivíduos representados no telejornalismo. É digno de nota que nos anos de 1999 e 2000 a mesma emissora pautou uma série de matérias jornalísticas sobre a agressividade da raça pitbull, destacando ataques feitos aos seres humanos, em uma clara inversão da regra "se um cachorro morde alguém não é notícia, mas se alguém morde um cachorro é notícia". Aliás, existe uma relação direta entre a ação do telejornalismo privilegiar temas e ações que fogem à normalidade, os fatos de grande impacto e os desvios (em geral negativos) do comportamento humano - honrando a máxima de que "más notícias são boas notícias" - e a valorização das notícias animais, que funcionam como um contraponto/ exemplo de bondade e dedicação. Essa curiosa inversão - as qualidades humanas colocadas no animal e o ser humano marcado pelos instintos destrutivos - dá uma nova forma a apresentação dos animais de estimação nos telejornais. Trata-se do animal humanizado e do homem desumanizado.

É nesse contexto, e sempre lembrando que o telejornalismo busca estar atento às mudanças sociais, que os cachorros apresentados no telejornalismo da Rede Globo de televisão são apresentados como filhos que fazem parte, inclusive, do orçamento doméstico com consultas periódicas a veterinários (nos mesmos moldes do pediatra), brinquedos, mobília e uma adaptação da estrutura da residência para abrigar um novo membro da família que para essas pessoas só se difere porque late e têm pelos, mas que de forma geral é também tratado como gente.

Essa relação, é claro, se insere nessa estrutura capitalista de produção e aproveitamento de uma sociedade que se abre para entender como necessário o que até a bem pouco tempo seria supérfluo: as próprias composições de moradia e móveis se modificam, 
com camas de casal sendo vendidas com espaços adaptados para o cachorro e portas que recebem novos recortes para o trânsito livre do animal.

No entanto, é importante lembrar que ao tentar espelhar a realidade, o telejornalismo estetiza e interfere nessa realidade. Nesse sentido, fica claro que a relação ser humano-animal apresentada no telejornalismo espelha apenas uma parte (em geral incompleta) da realidade, e está apoiada, sobretudo, em interesses comerciais evidentes - seja como estratégia para conquistar o coração dos simpatizantes dos animais, seja porque se revela nesse ponto um importante contraponto a um conteúdo agressivo e violento que caracteriza os telejornais neste início de século, seja também como a consolidação de um novo espaço para comercialização e lucro de produtos voltados para esse público.

Ao tentar espelhar a realidade, o telejornalismo estetiza e interfere nessa realidade. Embora a inclusão dos animais domésticos na pauta do telejornalismo seja uma aparente novidade, trata-se apenas de uma nova aparência para uma estratégia antiga, que, aliás, já parece tão eficiente.

\section{Referências}

BOURDIEU, P. Sobre a televisão. Rio de Janeiro: Jorge Zahar, 1997.

FOLHA. Jornal Nacional marca pior média de audiência de sua história na prévia. Disponível em: <http:// f5.folha.uol.com.br/televisao/2014/04/14.39663-jornal-nacional-marca-pior-media-de-audiencia-de-sua-historia-na-previa.shtml>. Acesso em: 10 jan. 2015.

GALEANO, E. A caminho de uma sociedade da incomunicação? In: MORAES, D. (Org.). Sociedade midiatizada. Rio de Janeiro: Mauad, 2006. p. 149-154.

GIDDENS, A. As consequências da modernidade. São Paulo: Unesp, 1991.

GROTH, O. O poder cultural desconhecido: fundamentos da Ciência dos Jornais. Tradução de Liriam Sponholz. Petrópolis: Vozes, 2011.

KELH, M. R. Eu vi um Brasil na TV. In: COSTA, A.; SIMÕES, I. F.; KEHL, M. R. Um país no ar: a história da TV brasileira em 3 canais. São Paulo: Brasiliense; Funarte, 1986.

LUHMANN, N. Introdução à teoria dos sistemas. Petrópolis: Vozes, 2011.

MARCONDES FILHO, C. A saga dos cães perdidos. Comunicação e Jornalismo. São Paulo: Hacker, 2000.

PERELMAN, C.; OLBRECHTS-TYTECA, L. Tratado de la Argumentación: la nueva retórica. Madri: Editorial Gredos, 1989.

PORCELLO, F. A. C. TV e poder: as relações sombras que ajudaram a fazer a história recente do Brasil. In PEREIRA JÚNIOR, A. E. V.; MOTA, C. L.; PORCELLO, F. A. C. Telejornalismo: a nova praça pública. Florianópolis: Insular, 2006. p.145-166. 
REY MORATÓ, J. Comunicación política, internet y campañas electorales: de la teledemocracia a la ciberdemocr@cia. Madri: Tecnos, 2007.

REZENDE, G. J. O papel do código verbal no telejornalismo. São João del-Rei: Funrei, 1997.

TEMER. A. C. R. P. Notícias \& Serviços nos telejornais da Rede Globo. Rio de Janeiro: Sotese, 2002.

WEBER, M. O conceito de casta. In IANNI, O. (Org.) Teorias da estratificação social: leituras de sociologia. São Paulo: Editora Nacional, 1972. p. 136-163.

WITTGENSTEIN, L. Investigaciones filosóficas. Barcelona: Crítica, 2008. 